\title{
Pengenalan Sidik Jari Pada Absensi Guru \& Pegawai Dengan Algoritma Perceptron
}

\author{
Adya Zizwan Putra \\ Address: Universitas Prima Indonesia /Teknik Informatika, Indonesia \\ Email: adyazizwanputra@unprimdn.ac.id
}

\begin{abstract}
Abstrak
Sidik jari adalah hasil reproduksi dari kulit permukaan jari, baik yang disengaja diambil / dicapkan dengan tinta maupun bekas yang ditinggalkan pada benda. Bentuk pokok sidik jari ditentukan oleh lapisan epidermal kulit, dimana apabila terjadi kerusakan pada lapisan ini akan bersifat sementara. Sidik jari yang ada pada seseorang adalah permanent dan karakteristik dan bentuknya terjaga dari lahir sampai mati. Selain itu berdasarkan hasil eksperimen Galton terbukti tidak ada dua orang mempunyai sidik jari yang sama, bahkan pada kembar identik pun ditemukan sidik jari yang berbeda meskipun mereka sama . Sehingga sidik jari dapat digunakan sebagai identitas seseorang dalam sistem keamanan. Perceptron merupakan bentuk jaringan syaraf yang sederhana, biasanya digunakan untuk mengklasifikasikan suatu tipe pola tertentu yang sering dikenal dengan pemisahan secara linear. Walaupun merupakan bentuk jaringan yang sederhana dan memiliki keterbatasan dalam pengenalan pola, perceptron dapat menyelesaikan masalah dengan baik dibanding jaringan lain apabila data dapat dipisahkan secara linear. Apabila data tidak dapat dipisahkan secara linear maka dapat dilakukan prepocessing terlebih dahulu untuk menghasilkan data yang dapat dipisahkan secara linear, atau menggunakan banyak perceptron dengan lapisan ganda, atau menggunakan jaringan jenis lain seperti back propagation. Pada tugas parket kerja lapangan ini penulis mencoba untuk menggunakan metode perceptron dengan representasi biner (0/1). maksudnya, target yang diinginkan akan direprentasikan dengan nilai 1 dan target yang tidak diinginkan akan direprentasikan dengan nilai 0 . Nilai target ini dapat dihasilkan oleh jaringan dengan fungsi aktivasi hardlim yang hanya dapat digunakan pada metode perceptron dan tidak dapat digunakan pada metode lain.
\end{abstract}

\section{Keywords - 3-5 sidik jari, perceptron, Jaringan syaraf tiruan}

\section{Latar Belakang}

Kecerdasan buatan merupakan salah satu bagian ilmu komputer yang membuat agar mesin (komputer) dapat melakukan pekerjaan seperti dan sebaik yang dilakukan oleh manusia. Kecerdasan buatan dibagi dalam tiga cabang, yaitu : sistem pakar (Knowledge based information processing), jaringan syaraf tiruan (artificial neural network), dan sistem kecerdasan hibrida. Sistem JST (Jaringan Syaraf Tiruan / Artificial Neural Network ANN) merupakan sistem yang menyerupai jaringan syaraf manusia.

Jaringan syaraf tiruan adalah model kasar dari syaraf sungguhan. Telah banyak bidang dan penelitian yang menggunakan teknik JST terutama pada sistem pengenalan pola seperti citra, suara, pengenalan huruf cetak, kode pos dan lain-lain.

Program StudiTeknikInformatika

Universitas Prima Indonesia (UNPRI) Medan
Pada tugas laporan kerja lapangan ini penulis mencoba memanfaatkan JST dengan aturan pelatihan perceptron untuk pengenalan sidik jari.

Sidik jari adalah hasil reproduksi dari kulit permukaan jari, baik yang disengaja diambil / dicapkan dengan tinta maupun bekas yang ditinggalkan pada benda. Bentuk pokok sidik jari ditentukan oleh lapisan epidermal kulit, dimana apabila terjadi kerusakan pada lapisan ini akan bersifat sementara. Sidik jari yang ada pada seseorang adalah permanent dan karakteristik dan bentuknya terjaga dari lahir sampai mati. Selain itu berdasarkan hasil eksperimen Galton terbukti tidak ada dua orang mempunyai sidik jari yang sama, bahkan pada kembar identik pun ditemukan sidik jari yang berbeda meskipun mereka sama . Sehingga sidik jari dapat digunakan sebagai identitas seseorang dalam sistem keamanan. 
Metode perceptron berguna sebagai pengklasifikasi. Perceptron dapat mengklasifikasi input vektor yang dapat dipisahkan secara linear dengan baik. Untuk pengenalan pola, perceptron akan melakukan pelatihan berulangulang untuk semua kemungkinan pola yang ada hingga jaringan dapat mengerti polanya (ditandai dengan samanya semua keluaran jaringan dengan target yang diinginkan). Sedangkan pada jaringan Hebb, pelatihan hanya dilakukan dalam satu siklus pelatihan walaupun jaringan belum mengenali pola tersebut.

Metode perceptron merupakan jaringan syaraf tiruan dengan layar tunggal yang memiliki keterbatasan dalam pengenalan pola. Kelemahan ini ditanggulangi dengan menambahkan satu/beberapa lapisan tersembunyi diantara lapisan masukan dan keluaran. Meskipun penggunaan lebih dari satu lapisan tersembunyi memiliki kelebihan manfaat untuk beberapa kasus, namun pelatihannya memerlukan waktu yang lama. Penambahan lapisan ini dapat dilakukan dengan metode backpropagation.

Metode backpropagation melatih jaringan untuk mendapatkan keseimbangan antara kemampuan jaringan untuk mengenali pola yang digunakan selama pelatihan serta kemampuan jaringan untuk memberikan respon yang benar terhadap pola masukan yang serupa (tapi tidak sama) dengan pola yang dipakai selama pelatihan. Apabila pola masukan sama maka jaringan dapat mengenalinya, sedangkan apabila tidak sama maka jaringan akan mampu mengenali dengan benar $90 \%$ pola dari 800 pola masukan ( jaringan dengan 80 bobot dan tingkat akurasi 0.1).

Perceptron merupakan bentuk jaringan syaraf yang sederhana, biasanya digunakan untuk mengklasifikasikan suatu tipe pola tertentu yang sering dikenal dengan pemisahan secara linear. Walaupun merupakan bentuk jaringan yang sederhana dan memiliki keterbatasan dalam pengenalan pola, perceptron dapat menyelesaikan masalah dengan baik dibanding jaringan lain apabila data dapat dipisahkan secara linear. Apabila data tidak dapat dipisahkan secara linear maka dapat dilakukan prepocessing terlebih dahulu untuk menghasilkan data yang dapat dipisahkan secara linear, atau menggunakan banyak perceptron dengan lapisan ganda, atau menggunakan jaringan jenis lain seperti back propagation.

Pada tugas parket kerja lapangan ini penulis mencoba untuk menggunakan metode perceptron dengan representasi biner $(0 / 1)$. maksudnya, target yang diinginkan akan direprentasikan dengan nilai 1 dan target yang tidak diinginkan akan direprentasikan dengan nilai 0 . Nilai target ini dapat dihasilkan oleh jaringan dengan fungsi aktivasi hardlim yang hanya dapat digunakan pada metode perceptron dan tidak dapat digunakan pada metode lain
Masalah yang akan diteliti dalam praktek kerja lapangan ini dapat dirumuskan sebagai berikut :

1. Bagaimana menganalisis jaringan syaraf tiruan dengan aturan perceptron dengan data yang siap olah dan pengukuran dalam melakukan pengenalan sidik jari hanya berdasarkan karakteristik bifurcation dan ridge ending pada sidik jari.

2. Pengukuran hasil dilakukan dengan menggunakan statistika deskriptif.

3. Bagaimana merancang dan membuat jaringan syaraf tiruan untuk pengenalan sidik jari dengan aturan perceptron

\section{Metode}

Pada penelitian ini menggunakan pendekatan R\&D (Research and Development), maka berikut ini adalah metode penelitiannya yaitu sebagai berikut:

Adapun beberapa teknik yang digunakan dalam pengumpulan data dari penelitian yaitu:

1. Observasi merupakan teknik pengumpulan data dengan melakukan tinjauan langsung ke tempat studi kasus dimana akan dilakukan penelitian.

2. Teknik wawancara ini dilakukan untuk mendapatkan informasi tambahan dari pihak-pihak yang memiliki wewenang dan berinteraksi langsung dengan sistem yang akan dirancang sebagai sumber data.

3. Studi Kepustakaan

Studi kepustakaan merupakan salah satu elemen yang mendukug sebagai landasan teoritis peneliti untu mengakaji masalah yang dibahas. Dalam hal ini, peneliti meggunakan beberapa sumber kepustakaan diaantaranya: Buku, Jurnal Nasional, Jurnal Internasional dan sumber-sumber lainnya.

Prosedur pemodelan dengan jaringan syaraf tiruan secara umum terdiri dari empat langkah yaitu:

1. Penyiapan data

2. Pemilihan arsitektur

3. Pembelajaran (learning )

4. Pengujian (testing)

Untuk menilai kedekatan atau kecocokan dengan menggunakan fungsi objektif atau fungsi kesalahan yang merupaka persamaan dari perhitungan dan pengamatan. Bentuk dari fungsi objektif ini digunakan kesalahan absolute rata-rata (KAR). Persamaan yang diformulasikan (Hadihardaja 2005)

Di mana :

: Debit hasil perhitungan

: Debit hasil pengamatan

$\mathrm{n}$ : Banyak data 
Setiap pola-pola informasi input dan output yang diberikan ke dalam JST diproses dalam neuron. Neuronneuron tersebut terkumpul di dalam lapisan-lapisan yang disebut neuron layers

Metode jaringan perceptron merupakan model yang paling baik pada saat itu. Model ini ditemukan oleh Rosenblatt (1962) dan Minsky - Papert (1969). Algoritma pelatihan perceptron adalah sebagai berikut :

1.Inisialisasi semua bobot dan bias (biasanya=0).

Set learning rate. . Untuk penyederhanaan set sama dengan 1. Set nilai threshold ( untuk fungsi aktivasi.

2. Untuk setiap pasangan pembelajaran $\mathrm{s}-\mathrm{t}$, kerjakan: a.Set aktivasi unit input, ditunjukkan dengan persamaan (1).

b.hitung respon untuk unit output, ditunjukkan dengan persamaan (2).

c.Masukkan ke dalam fungsi aktivasi, ditunjukkan dengan persamaan (3).

d.Bandingkan nilai output jaringan y dengan target t.

jika y t, lakukan perubahan bobot dan bias, ditunjukkan dengan persamaan (4) dan persamaan (5).

3. Lakukan iterasi terus-menerus hingga semua pola memiliki output jaringan yang sama dengan targetnya. Artinya bila semua ouput jaringan sama dengan target maka jaringan telah mengenali pola dengan baik dan iterasi dihentikan. Algoritma pelatihan perceptron digunakan baik untuk input biner maupun bipolar, dengan tertentu, dan bias yang dapat diatur. Satu siklus pelatihan yang melibatkan seluruh data input disebut satu epoch.

\section{Hasil}

Perceptron termasuk salah satu bentuk jaringan syaraf yang sederhana. Perceptron biasanya digunakan untuk mengklasifikasikan suatu tipe pola tertentu yang sering dikenal dengan pemisahan secara linear. Pada dasarnya, perceptron pada jaringan syaraf dengan satu lapisan memiliki bobot yang bisa diatur dan suatu nilai ambang (threshold). Algoritma yang digunakan oleh aturan perceptron ini akan mengatur parameter-parameter bebasnya melalui proses pembelajaran. Nilai threshold (司) pada fungsi aktivasi adalan non negatif. Fungsi aktivasi ini dibuat sedemikian rupa sehingga terjadi pembatasan antara daerah positif dan daerah negative.



Gambar 1. Pembatasan Linier dengan Peceptron

Garis pemisah antara daerah positif dan daerah nol memiliki pertidaksamaan:

$w 1 \times 1+w 2 \times 2+b>\theta$

Sedangkan garis pemisah antara daerah negatif dengan daerah nol memiliki pertidaksamaan:

$w 1 \times 1+w 2 \times 2+b<-\theta$

Misalkan kita gunakan pasangan vektor input s dan vektor output sebagai pasangan vektor yang akan dilatih Algoritma: Inisialisasi semua bobot dan bias:(untuk sederhananya set semua bobot dan bobot bias sama dengan nol).

Tingkat kemiripan antara citra query dengan citra pustaka dihitung dengan menggunakan metrika model jaringan syaraf tiruan jenis Perceptron. Konsep dasar Jaringan Syaraf Tiruan adalah dengan menirukan sel-sel otak manusia. Pada dasarnya cara kerja JST tersebut dengan cara menjumlahkan hasil kali dari nilai masukan dengan nilai bobotnya. Pada Gambar dibawah ini diper-lihatkan serangkaian masukan X1 ... Xn. Setiap masukan akan dikalikan berturut-turut dengan bobot $\mathrm{W} 1$...Wn dengan demikian hasil kali keluaran akan sama dengan:

$Y=X 1 . W 1+X 2 . W 2+\ldots+X n . W n$



Gambar 2. Skema JST

Cara kerja metode peceptron dalam melakukan pengenalan sidik jari, yaitu citra yang diinputkan dilakukan training untuk mendapatkan bobot-bobot terbaru. Bobot-bobot tersebut digunakan untuk mengubah citra asli menjadi citra grayscale, setelah mendapat nilai citragrayscale akan dirubah kembali 
menjadi citra biner untuk dapat diterapkan kedalam metode peceptron. Sebagai contoh kasus pengenalan sidik jari seperti pada gambar dibawah ini:

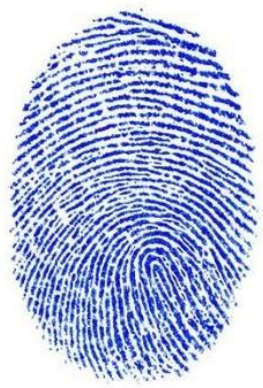

Gambar 3. Citra Sidik Jari Warna

Pada gambar 3 diatas nilai pixel yang diperoleh dari citra asli dengan menggunakan matrix $5 \times 5$ untuk mendapatkan nilai pixsel Red, Blue dan Green, maka nilai pixel yang diperoleh seperti pada table dibawah ini:

Tabel 1. Hasil Pixsel Sidik Jari

\begin{tabular}{|l|l|l|l|l|}
\hline R: 181 & R: 181 & R: 180 & R: 179 & R: 177 \\
B: 131 & G: 148 & G: 147 & G: 146 & G: 144 \\
\hline R: 181 & R: 181 & R: 180 & R: 179 & R: 178 \\
G: 148 & G: 148 & G: 147 & G: 146 & G: 145 \\
B: 131 & B: 131 & B: 130 & B: 129 & B: 128 \\
\hline R: 180 & R: 180 & R: 179 & R: 178 & R: 176 \\
G: 147 & G: 147 & G: 146 & G: 145 & G: 145 \\
B: 130 & B: 130 & B: 129 & B: 128 & B: 128 \\
\hline R: 179 & R: 176 & R: 176 & R: 175 & R: 175 \\
G: 146 & G: 143 & G: 143 & G: 142 & G: 142 \\
B: 129 & B: 126 & B: 126 & B: 125 & B: 125 \\
\hline R: 179 & R: 177 & R: 177 & R: 176 & R: 175 \\
G: 146 & G: 144 & G: 144 & G: 143 & G: 142 \\
B: 129 & B: 127 & B: 127 & B: 126 & B: 125 \\
\hline
\end{tabular}

Pelatihan dan pengujian data dengan metode perceptron dengan menggunakan tiga pola data yang berbeda serta masing-masing target yang berbeda pula. Adapun bentuk pola data pertama yang akan dilatih dan diuji ditunjukkan pada Tabel 2 dengan data input biner dan data target biner.

Tabel 2 Data Input Biner dengan Data Target Biner

\begin{tabular}{|l|l|l|l|l|l|l|l|}
\hline \multicolumn{2}{|c|}{ Data Input } & \multicolumn{7}{|c|}{ Data Target } \\
\hline $\mathbf{X}_{\mathbf{1}}$ & $\mathbf{X}_{\mathbf{2}}$ & OR & AND & NOR & NAND & Ex-OR & Ex-NOR \\
\hline 0 & 0 & 0 & 0 & 1 & 1 & 0 & 1 \\
\hline 1 & 0 & 1 & 0 & 0 & 1 & 1 & 0 \\
\hline 0 & 1 & 1 & 0 & 0 & 1 & 1 & 0 \\
\hline 1 & 1 & 1 & 1 & 0 & 0 & 0 & 1 \\
\hline
\end{tabular}

Tabel 3 Data Input Bipolar dengan Data Target Bipolar

\begin{tabular}{|c|c|c|c|c|c|c|c|}
\hline \multicolumn{2}{|c|}{ Data Input } & \multicolumn{6}{|c|}{ Data Target } \\
\hline $\mathbf{x}_{1}$ & $\mathrm{x}_{2}$ & $\begin{array}{l}\mathbf{O} \\
\mathrm{R}\end{array}$ & AND & NOR & NAND & Ex-OR & Ex-NOR \\
\hline-1 & -1 & -1 & -1 & 1 & 1 & -1 & 1 \\
\hline 1 & -1 & 1 & -1 & -1 & 1 & 1 & -1 \\
\hline-1 & 1 & 1 & -1 & -1 & 1 & 1 & -1 \\
\hline 1 & 1 & 1 & 1 & -1 & -1 & -1 & \begin{tabular}{|l|l}
1 \\
\end{tabular} \\
\hline
\end{tabular}

Tabel 4 Data Input Biner dengan Data Target Bipolar (Hybrid)

\begin{tabular}{|l|l|l|l|l|l|l|l|}
\hline \multicolumn{2}{|l|}{ Data Input } & \multicolumn{7}{|c|}{ Data Target } \\
\hline $\mathbf{X}_{\mathbf{1}}$ & $\mathbf{X}_{\mathbf{2}}$ & $\mathbf{O R}$ & AND & NOR & NAND & Ex-OR & EX-NOR \\
\hline 0 & 0 & -1 & -1 & 1 & 1 & -1 & 1 \\
\hline 1 & 0 & 1 & -1 & -1 & 1 & 1 & -1 \\
\hline 0 & 1 & 1 & -1 & -1 & 1 & 1 & -1 \\
\hline 1 & 1 & 1 & 1 & -1 & -1 & -1 & 1 \\
\hline
\end{tabular}

Pola data pada Tabel diatas untuk pengenalan sidik jari adalah pola data dengan dua data input dan satu data target yang bervariasi dengan learning rate dan maksimum epoch yang sama pada pengujian data sebelumnya, yaitu learning rate $=0.7$ maksimum epoch $=$ 150000. Adapun hasil pelatihan dan pengujian dari data pada Tabel diatas dapat dilihat pada Tabel dibawah ini.

Tabel 5 Hasil pelatihan dan Pegujian dari tabel

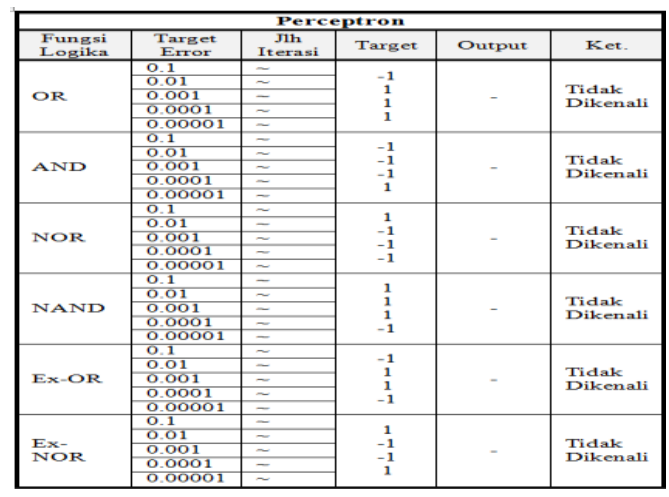

Langkah selanjutnya adalah mendeteksi batas persegi panjang dari area hitam yang dihasilkan, yang geometris pusatakan menjadi pusat $8 \times 8$ piksel. Gambar 3.8 menunjukkan salah satu hasil dari preprocessing dan segmentasi dari sampel pertama dari kelas sidik jari. Sampel gambar sisa sidik jari masing-masing kelas yang tersegmentasi dengan cara yang berbeda. Gambar 3.9 menunjukkan salah satu hasil yang dicapai. 
Prosessegmentasi ditunjukkan pada Gambar 3.10 digunakan sebagai masukan untuk ekstraksi fitur.

Klasifikasi pada penelitian ini menggunakan JST peceptron untuk mendapatkan hasil klasifikasi. Pembentukan klasifikasi dimulai dengan memberikan input gambar dari feature extraction dan menkonversi format data tersebut dengan Graylevel co-occurrence matrix (GLCM) untuk mendapatkan data input yang akan digunakan untuk proses klasifikasi.

Kemudian dari hasil ekstrasi dari GLCM menjadi input yang terdiri dari jaringan syaraf tiruan yaitu corelasi, contras, homogenity, entropy, dan energi, nilai masuk dari $y 1-y 5$, selanjutnya menghitung output dari $\boldsymbol{A} 1, y$ 1 kali bobot $y 1$ ke $\boldsymbol{A} 1$ ditambah y 2 kali bobot $y 2$ ke $\boldsymbol{A} 1$ samapai ke $y 5$ setelah itu dapat nilai, kemudian dihitung menggunakan rumus sigmoid fungsi aktivasi untuk mendapatkan output jaringan $\boldsymbol{A} 1$ kali bobot $\boldsymbol{A} 1$ ke $z 1$ sampai $\boldsymbol{A} 7$ kali bobot $\boldsymbol{A} 7$ ke $z 1$ output pada layer output merupakan output dari jaringan syaraf tiruan sedangkan output ada 2 hidden layer disesuaikan dengan pengujian, output 2 karena punya 2 kelas, yaitu Kelas $1: 00$, Kelas 2 : 11 dan Kelas 3 : 10 . Kemudian system akan membuat klasifikasi dengan metode JST Peceptron.

\section{Kesimpulan}

Setelah perangkat lunak pengamanan data dirancang dan dilakukan pengujian maka kesimpulan yang dapat diambil adalah sebagai berikut :

1. Pada kasus mengenali sidik jari maka dilakukan pengujian metode perceptron sangat baik dalam mengenali pola data input biner dan target biner, khususnya pada fungsi logika Ex-OR dan Ex-NOR sehingga sidik jari.

2. Metode perceptron dapat mengenali pola sidik jari absensi guru khususnya dalam penggunaan data input biner dan target biner pada fungsi logika OR dan NOR dengan jumlah iterasi 20.

3. Metode perceptron sangat baik digunakan sebagai pemrosesan awal (untuk mengekstraksi ciri citra sidik jari) dan jaringan syaraf tiruan sebagai elemen pengenal dalam sistem pengenalan citra sidik jari, sehingga dapat dikembangkan untuk sistem pengenalan data sidik jari.

4. Hal utama untuk meningkatkan keakuratan pengenalan sidik jari yaitu dapat dilakukan pengambilan titik acuan dari gambar sidik jari supaya gambar sidik jari yang diambil dapat dilakukan rotasi oleh sistem. Sedangkan untuk lebih meningkatkan kecepatan pencocokkan, data sidik jari disimpan dengan menggunakan klasifikasi tipe sidik jari.
5. Ukuran basis data tidak berpengaruh signifikan terhadap waktu pengenalan citra

Adapun saran yang dapat diberikan adalah sebagai berikut :

1. Dari hasil di atas, maka disarankan untuk mengembangkan penelitian ini kearah identi-fikasi citra sidik jari disekolah-sekolah untuk melakukan absensi secara digital yang datanya lebih kompleks, sehingga dapat membantu pihak sekolah dalam melakukan absensi.

2. Aplikasi dapat dikembangkan dengan menambahkan metode Jaringan Syaraf Tiruan (JST) lainnya, seperti: Learning Vector Quantization (LVQ), Perceptron , jaringan Kohonen dan metode JST lainnya, sehingga dapat dianalisis dan diketahui metode pengenalan bentuk yang terbaik.

3. Aplikasi ini dapat menjadi dasar bagi aplikasi pengenalan bentuk lainnya yang menggunakan metode jaringan syaraf tiruan, seperti: aplikasi pengenalan karakter tulisan dan aplikasi pengenalan sidik jari.

\section{References}

[1] Hermawan, A. "Jaringan Syaraf Tiruan Teori dan Aplikasi". Penerbit Andi.

Yogyakarta, 2016.

[2] Siang, Jong Jek. "Jaringan Syaraf Tiruan \& Pemrogramannya Menggunakan Matlab". Yogykarta : Andi, 2015.

[3] Wibowo, Aditya., Hidayanto, Achmad., Ajulian, Ajub. (2016). Pengenalan Huruf Jawa Tulisan Tangan Menggunakan Jaringan Saraf Tiruan Perambatan Balik Dengan Fuzzy Feature Extraction. Semarang: Jurusan Teknik Elektro Universitas Diponegoro.

[4] Siang, J J. (2015). Jaringan Syaraf Tiruan dan Pemrogramannya Menggunakan Matlab. Edisi Kedua. Yogyakarta: Andi.

[5] Puspitaningrum, Diyah. (2016). Pengantar Jaringan Saraf Tiruan. Yogyakarta: Andi. 